\title{
Urinary screening for potentially genotoxic exposures in a chemical industry
}

\author{
G AHLBORG JR, ${ }^{12}$ B BERGSTRÖM,${ }^{1} \mathrm{C}$ HOGSTEDT, ${ }^{34} \mathrm{P}^{2}$ EINISTÖ,${ }^{5}$ AND MARJA SORSA ${ }^{5}$ \\ From the Departments of Occupational Medicine, Regional Hospital, ${ }^{1}$ S-701 85 Örebro, and University \\ Hospital, ${ }^{2}$ S-581 85 Linköping, Section of Occupational Medicine, ${ }^{3}$ Research Department, National Board of \\ Occupational Safety and Health, S-171 84 Solna, and Department of Occupational Medicine, ${ }^{4}$ Karolinska \\ Hospital, S-104 01 Stockholm, Sweden, and Department of Industrial Hygiene and Toxicology, ${ }^{5}$ Institute of \\ Occupational Health, SF-002 90 Helsinki 29, Finland
}

\begin{abstract}
Mutagenic activity, measured by the bacterial fluctuation assay and thioether concentration in urine from workers at a chemical plant producing pharmaceuticals and explosives, was determined before and after exposure. Of 12 groups only those exposed to trinitrotoluene $(n=14)$ showed a significant increase in mutagenic activity using Salmonella typhimurium TA 98 without any exogenous metabolic system. The same strain responded only weakly when the S-9 mix was used; with Escherichia coli WP2 uvrA no effect of exposure was observed. Urinary thioether concentration was higher among smokers than among non-smokers, but occupational exposure had no effect. Urinary mutagenicity testing may be a useful tool for screening potentially genotoxic exposures in complex chemical environments.
\end{abstract}

Exposure to genotoxic substances is thought to be associated with environmentally induced cancers. In workplaces where several potentially genotoxic substances are handled there is a need for methods to estimate biologically relevant exposures. During the past decade several such methods have been developed and systems using bacterial strains to detect mutagens are widely used to test single chemicals. These tests, however, have also been used to estimate the total content of mutagens excreted in the urine of exposed workers. ${ }^{1}$ Occupational groups exposed to anaesthetic gases, ${ }^{23}$ cytotoxic drugs, ${ }^{4}$ epichlorohydrin, ${ }^{5}$ air pollutants in foundries, ${ }^{6}$ coke plants, ${ }^{7}$ and the carbon electrode industry ${ }^{8}$ have been studied. Various enzyme treatments have often been combined with the test system in order to activate metabolically conjugated substances and premutagens.

An alternative to the conventional plate incorporation assay (Ames test) is the more sensitive bacterial fluctuation test developed by Green et al. ${ }^{9}$ Among occupationally exposed groups, rubber workers ${ }^{10}$ and hospital personnel handling cytostatic drugs ${ }^{11}$ have shown increased mutagenic activity in the urine compared with unexposed controls. Furthermore, the average mutagenic activity decreased when the exposure was lowered. ${ }^{12}$

Received 19 November 1984

Accepted 11 February 1985
Many genotoxic substances bind to macromolecules such as cellular proteins or nucleic acids and are often metabolised and conjugated with glutathione before excretion in the urine as thioethers such as mercapturic acid. Therefore, thioether concentration in the urine has been used as an estimate of exposure to potentially genotoxic substances among smokers, ${ }^{1314}$ rubber workers, ${ }^{15}$ workers exposed to carbon disulphide and methyl chloride, ${ }^{16}$ incinerator workers, ${ }^{17}$ and nurses handling cytotoxic drugs. ${ }^{18}$

The study presented in the present paper was initiated in an attempt to identify groups of workers with an uptake of potentially genotoxic substances in a chemical plant producing a large variety of pharmaceuticals and explosives. An earlier epidemiological study of the plant had shown an increased risk of gastric cancer among those employed before 1968 (Andersson et al, to be published). It was not possible, however, to relate this finding to any specific work process or exposure in that retrospective study.

Urine from 12 different groups of workers at the plant were assayed for mutagenicity and thioether concentration in samples taken after an exposed shift and compared with samples after a long vacation.

\section{Study groups and urine sampling}

All the 119 workers in the chemical process departments at the plant were asked to take part in the 
study and only four refused. The participants were asked to deliver three urine samples, one after four weeks vacation (unexposed sample), one before a workshift after several days work (preshift sample), and one after the same shift (exposed sample). Thereby each individual could be used as his/her own control by comparing the mutagenic activity in the exposed sample with the unexposed and the thioether concentration in the exposed sample with the preshift sample. A total of 115 unexposed samples were originally collected, but owing to replacements only 97 exposed samples were obtained from 80 men and 17 women. Three of these were not able to give a preshift sample.

On both days of sampling, each worker completed a questionnaire concerning smoking habits and alcohol consumption, diet, health, and medication. Special attention was paid to the $\mathbf{4 8}$ hours preceding the sampling.

Four weeks of vacation had preceeded most of the unexposed samples but, in addition, 16 samples delivered after only at least four days leave from work were also accepted and regarded as unexposed. As the exposure was generally considered to be highest during the morning shifts compared with evening shifts, all the exposed samples were collected in the middle or at the end of a morning shift. The unexposed and preshift samples were collected before the worker entered the work area. All samples were collected in plastic bottles and divided into several portions before freezing to $-20^{\circ} \mathrm{C}$, at which temperature they were transported to the laboratory and kept until analysed. According to earlier experience such preservation has no effects on the urinary mutagenic activity. ${ }^{19}$

\section{Exposure}

A careful characterisation of the exposure at each of the participating production units was performed. Detailed lists of raw materials and products handled were made as were descriptions of each step in the production process. Earlier data of air concentrations of important chemicals were completed by new measurements where this was considered necessary to achieve an appropriate estimate of the ambient concentrations. Some of these data are shown in table 1 with the 12 exposure categories. (A more detailed exposure specification is available on request from GA.)

The main chemical processes take place in closed systems and hence highest air concentrations of chemicals occur mainly at the workplaces where the final products are dryed and packed, and to a certain extent where raw materials are added to the process machines. All deviations from the normal routine, such as process disturbances, leakages, or other inter- ruptions, were noted during the exposed shift by the occupational hygienist who followed up the workers.

\section{Methods and exclusions}

BACTERIALMUTAGENICITY ASSAY

The urine samples were concentrated on XAD-2 resin as described by Yamasaki and Ames. ${ }^{20}$ The bacterial fluctuation test was performed according to Falck ${ }^{21}$ using indicator strain Salmonella typhimurium TA 98 for frame shift mutagen detection and Escherichia coli WP2 uvrA for detection of base pair substitution mutagens. Metabolic activation was accomplished by adding rat liver homogenate (S-9 mix), prepared routinely from clophen A 50 induced Wistar rats. ${ }^{21}$ The B-glucuronidase activity of S-9 mix is approximately equivalent to 20 IV B-glucuronidase of Helix pomatia, ${ }^{21}$ and therefore no additional enzyme treatment was used.

The mutagenic activity of the urine was calculated as follows:

$$
\begin{gathered}
\text { Mutagenic } \\
\text { activity }
\end{gathered}=\frac{\begin{array}{c}
\text { Revertants in sample-revertants in } \\
\text { solvent control }
\end{array}}{\text { Creatinine (mmol) in urine sample }}
$$

The mutagenic activity was calculated separately for each of three to five dilutions of the concentrated sample. The dilution giving the highest mutagenicactivity was used for the calculation of the results.

\section{THIOETHER ANALYSIS}

The thioether content of the urine samples was analysed according to the method described by van Doorn et $a l^{13}$ with certain modifications. ${ }^{14}$ Each sample was divided into two portions which were analysed separately, and the mean value $(\mu \mathrm{mol} \mathrm{SH} / \mathrm{l})$ of the two was included in the results after creatinine correction (mmol/l; analysed according to Clark and Thompson ${ }^{22}$ ) giving a final value in $\mu \mathrm{mol} \mathrm{SH} / \mathrm{mmol}$ creatinine.

\section{EXCLUSIONS}

Very dilute urine has a low creatinine concentration. In calculating the mutagenic activity and the thioether concentration, correcting the values for a low creatinine content may carry a risk of overestimating the true excretion. Therefore we chose to exclude all samples with a creatinine concentration below $3.0 \mathrm{mmol} / 1$ (the low fifth percentile of the total material). Eight samples from eight individuals were thereby excluded.

Individuals with liver disease may have an altered or reduced metabolic capacity that could influence the biotransformation of genotoxic substances and the results. $^{23}$ Individuals with a significant increase (above the 97.5:th percentile value) in liver enzymes 
Table 1 Numbers of workers in each exposure group, substances produced, and maximum average air concentration measured in the workroom

\begin{tabular}{|c|c|c|c|}
\hline Group & $\begin{array}{l}\text { No of } \\
\text { workers }\end{array}$ & Production & $\begin{array}{l}\text { Maximum air concentration } \\
\left(\mathrm{mg} / \mathrm{m}^{3}\right)\end{array}$ \\
\hline $\begin{array}{l}\text { A } \\
\text { B } \\
\text { C } \\
\text { D } \\
\text { E } \\
\text { F } \\
\text { G } \\
\text { H } \\
\text { I } \\
\text { J } \\
\text { K } \\
\text { L }\end{array}$ & $\begin{array}{r}14 \\
6 \\
7 \\
8 \\
3 \\
12 \\
5 \\
4 \\
3 \\
7 \\
5 \\
7\end{array}$ & $\begin{array}{l}\text { Trinitrotoluene } \\
\text { o-, m-, p-Nitrotoluene } \\
\text { p-Nitrobenzoic acid } \\
\text { Dinitrobenzoic acid } \\
\text { p-Nitrobenzoylchloride } \\
\text { Aminobenzoic acid } \\
\text { Hexaminetetranitrate } \\
\text { Mesoinositolhexanicotinate } \\
\text { 5-Nitroisophthalic acid } \\
\text { Polyacrylates } \\
\text { Regaining acids }\left(\mathrm{HCI}, \mathrm{HNO}_{3}\right) \\
\text { Othert }\end{array}$ & $\begin{array}{l}0 \cdot 29 \\
2 \cdot 0(\mathrm{O}-\mathrm{NT}) \\
5 \cdot 4 \\
0 \cdot 6^{*} \\
3 \cdot 2^{*} \\
2 \cdot 6 \text { (Pyridine) } \\
1 \cdot 1^{*} \\
29 \cdot 1 \text { (Methylacrylate) } \\
-\end{array}$ \\
\hline
\end{tabular}

*Concentration of total organic dust.

†Repair and maintenance work (five workers) and production of mepivacaine (two workers).

(SGOT, SGPT, SALP, or SGT) were excluded from the results, ten in all.

Mutagenic activity cannot be measured when the sample is toxic to the indicator bacteria even at the lowest concentration. Such samples were excluded from the analyses of that particular test system. Ten individuals were lost for evaluation in the test using $S$ typhimurium TA 98 with S-9-mix, seven with $S$ typhimurium TA 98 without S-9-mix, and 11 with $E$ coli WP2 uvrA.

Seventy five individuals were finally tested for urine mutagenicity with $S$ typhimurium TA 98 without metabolic activation, 78 with $S$ typhimurium TA 98 without metabolic activation, 72 with $E$ coli WP2 uvrA with metabolic activation, 81 with analysis of thioether concentration in unexposed and exposed samples, and 77 analysed for thioether concentration in preshift and exposed samples. The excluded individuals were evenly distributed across the 12 groups.

\section{STATISTICAL METHODS}

For each of the 12 exposure groups the mean and standard deviations of the mutagenic activity and thioether concentrations were calculated. The difference between exposed and unexposed samples was tested for statistical significance using Student's $t$ test for paired observations and between different exposure groups with Student's $t$ test for independent samples. ${ }^{24}$ In those cases where the distributions strongly deviated from normal Wilcoxon's signed rank test or Wilcoxon's rank sum test was used (the result of Student's $t$ test is given for comparison). The $5 \%$ level has been applied with two tailed calculations $(\mathrm{p}<0.05)$.

\section{Results}

TOTAL STUDY POPULATION

In the total study population the mean mutagenic activity in exposed urine samples was significantly increased (fig 1 and table 2; p < 0.01) compared with unexposed samples tested with $S$ typhimurium TA 98 without exogenous metabolic system (S-9 mix). No differences between the exposed and unexposed samples were observed with the two other test systems used (fig la \& c), nor was the mean thioether concentration increased in the exposed samples compared with the preshift or unexposed samples.

\section{URINE MUTAGENICITY IN THE SEPARATE EXPOSURE GROUPS}

Only two of the 12 exposure groups showed an increased mutagenic activity in the exposed samples compared with the unexposed (table 3 ) in the test system using $S$ typhimurium TA 98 with metabolic activation-namely, the TNT (A) and hexaminetetranitrate $(\mathrm{G})$ groups. The differences did not, however, reach statistical significance. One individual in the hexaminetetranitrate group, who is a smoker, had a high mutagenic activity in the exposed sample (3510 rev/mmol creat) and therefore accounts for most of the observed increase of the group mean figure. There was a statistically significant $(\mathrm{p}<0.05)$ difference in mean mutagenic activity between the exposed samples in the TNT (A) group compared with the exposed samples in the other groups (B-L).

Those who smoked at least one cigarette during the 24 hours preceeding the urine sampling had higher average mutagenic activity than non-smokers (table 4). Only non-smokers exposed to TNT had an increased mutagenic activity after exposure $(\mathrm{p}<0.05)$.

The increase in mutagenic activity after exposure detected in the test system with $S$ typhimurium TA 98 without metabolic activation is almost totally explained by the increase in the group exposed to TNT (table 3). In this group the difference between exposed and non-exposed samples is statistically highly significant $(p<0.01)$, and the highest urine mutagenicity is found among the most highly exposed 

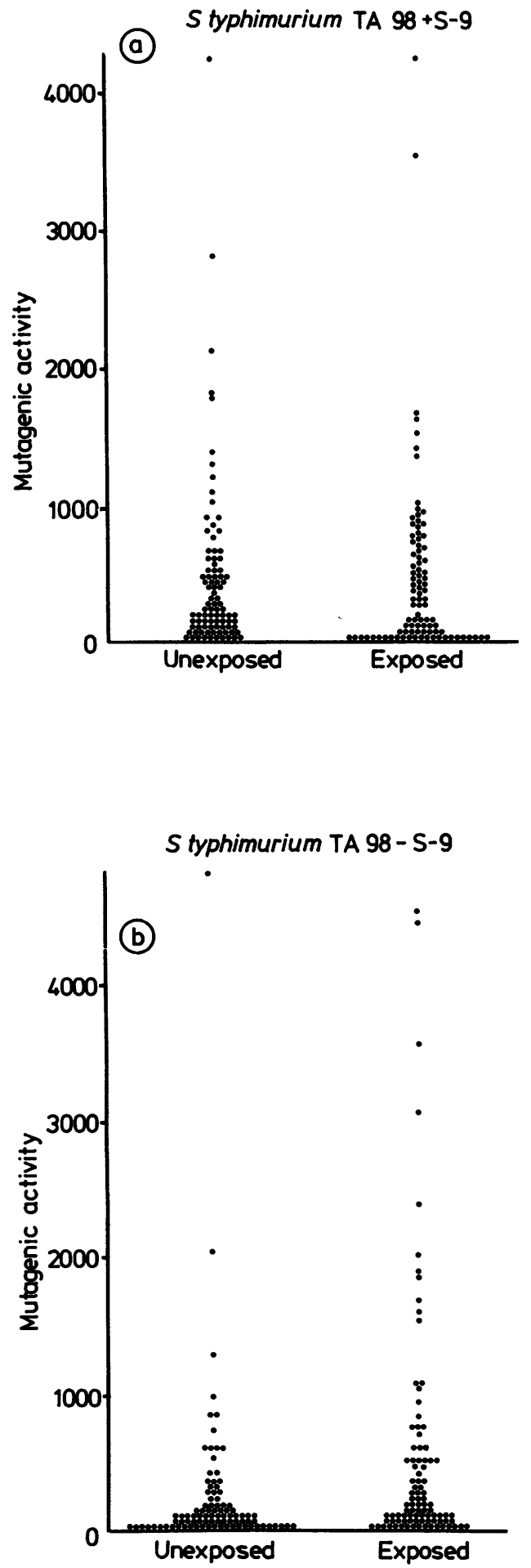

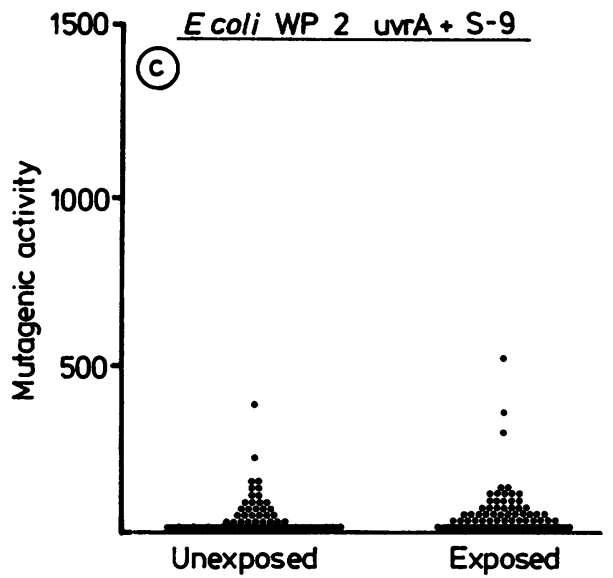

Fig 1 Distribution of mutagenic activity (numbers of revertants/mmol creatinine) in individual unexposed and exposed urine samples from all workers, tested with Salmonella typhimurium TA 98 with $(A)$ and without $(B)$ metabolic activation and Escherichia coli WP2 uvrA with metabolic activation $(C)$.

workers, those who work in the washing, drying, arfo packing departments. No difference between smokes and non-smokers is seen with this test system (table 4).

Only one individual exposed to TNT had a higher mutagenic activity in the unexposed sample com- $\frac{\varnothing}{\varnothing}$ pared with the exposed (fig 2). This was a male $\varrho$ smoker (10-20 cig/day) who had also consumed $\overrightarrow{\overrightarrow{0}}$ alcohol $(30 \mathrm{cl})$ the day before the exposed sampling.

No indication of base pair substitution mutagens from the work environment was found using the test system with $E$ coli WP2 uvrA with metabolic activation in any of the exposure subgroups. The highest mean value and the largest difference between the $\dot{0}$ exposed and unexposed samples was found in the group of workers regaining acids ( $\overline{\mathrm{x}} 99 ; \mathrm{SD} 149 ; \bar{d} 86)$. The TNT group showed low urine mutagenicity with $₹$ this test system ( $\bar{x} 45 ;$ SD 37; $\bar{d} 18$ ).

THIOETHER CONCENTRATIONS

None of the exposure subgroups showed any significant increase in mean thioether concentration o after exposure compared with preshift or unexposed $N$ samples. A male smoker who, at the time of sampling, was taking antibiotics and expectorants for an infection in the upper respiratory tract had an extremely high value in the preshift sample $(49.2 \mu \mathrm{mol} \mathrm{SH} / \mathrm{mmol} \stackrel{\odot}{\odot}$ creat). Smokers had higher thioether concentration $\stackrel{\mathcal{Q}}{\rightarrow}$ on average than non-smokers (table 5). 
Table 2 Mutagenic activity (rev/mmol creat), thioether ( $\mu \mathrm{mol}$ SH/mmol creat) and creatinine (mmol) concentration in urine samples from workers included in the study

\begin{tabular}{llccc}
\hline Test & $\begin{array}{l}\text { No of } \\
\text { workers } \dagger\end{array}$ & $\begin{array}{l}\text { Unexposed } \\
\text { samples } \ddagger\end{array}$ & $\begin{array}{l}\text { Preshift } \\
\text { samples } \ddagger\end{array}$ & $\begin{array}{c}\text { Exposed } \\
\text { samples }\end{array}$ \\
\hline TA 98 + S-9 & 75 & $406 \pm 464$ & - & $396 \pm 529$ \\
TA 98 - S-9 & 78 & $157 \pm 309$ & - & $473 \pm 844^{*}$ \\
WP2 uvrA + S-9 & 72 & $29 \pm 60$ & - & $36 \pm 63$ \\
Thioethers & 77 & $4 \cdot 0 \pm 2 \cdot 4$ & $4 \cdot 5 \pm 5 \cdot 8$ & $2 \cdot 2$ \\
Creatinine & 78 & $13 \cdot 4 \pm 6 \cdot 8$ & $17 \cdot 2 \pm 6 \cdot 6$ & $12 \cdot 6 \pm 5 \cdot 0$ \\
\hline
\end{tabular}

${ }^{*} \mathrm{p}<0.01$ (difference between exposed and unexposed samples; Wilcoxon's signed rank test and Student's $t$ test).

tOnly the number of workers with a result in both (mutagenic activity) or all three (thioether and creatinine concentration) samples are presented for each test system.

${ }_{+}$Mean \pm standard deviation.

Table 3 Mutagenic activity in urine for each exposure group analyzed with S typhimurium TA 98 with and without metabolic activation (S-9 mix)

\begin{tabular}{|c|c|c|c|c|c|c|}
\hline \multirow[t]{2}{*}{ Group } & \multicolumn{3}{|c|}{$+S-9$} & \multicolumn{3}{|c|}{$-S-9$} \\
\hline & No & Unexposed & Exposed & No & Unexposed & Exposed \\
\hline $\begin{array}{l}\text { A } \\
\text { B } \\
\text { C } \\
\text { D } \\
\text { E } \\
\text { F } \\
\text { G } \\
\text { H } \\
\text { I } \\
\text { J } \\
\text { K } \\
\text { L }\end{array}$ & $\begin{array}{r}13 \\
6 \\
5 \\
7 \\
3 \\
11 \\
5 \\
3 \\
3 \\
7 \\
5 \\
7\end{array}$ & $\begin{array}{l}467 \pm 480 \\
205 \pm 194 \\
241 \pm 181 \\
768 \pm 718 \\
221 \pm 351 \\
303 \pm 353 \\
410 \pm 340 \\
514 \pm 665 \\
248 \pm 354 \\
305 \pm 209 \\
301 \pm 422 \\
651 \pm 761\end{array}$ & 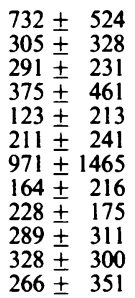 & $\begin{array}{r}14 \\
6 \\
6 \\
7 \\
3 \\
3 \\
11 \\
5 \\
4 \\
3 \\
7 \\
5 \\
7\end{array}$ & $\begin{array}{r}233 \pm 539 \\
36 \pm 40 \\
119 \pm 152 \\
137 \pm 184 \\
21 \pm 22 \\
315 \pm 446 \\
144 \pm 186 \\
82 \pm 114 \\
81 \pm 100 \\
215 \pm 224 \\
107 \pm 105 \\
49 \pm 70\end{array}$ & $\begin{array}{rr}1784 \pm & 1293^{*} \\
180 \pm & 213 \\
295 \pm & 408 \\
306 \pm & 184 \\
75 \pm & 13 \\
85 \pm & 107 \\
260 \pm & 309 \\
17 \pm \pm & 22 \\
289 \pm & 478 \\
190 \pm & 323 \\
130 \pm & 222 \\
226 \pm & 226\end{array}$ \\
\hline B-Lt & 62 & $393 \pm 464$ & $325 \pm 506$ & 64 & $140 \pm 234$ & $187 \pm 248$ \\
\hline
\end{tabular}

${ }^{*} \mathrm{p}<0.01$ (difference between exposed and unexposed samples; Wilcoxon's signed rank test and Student's $t$ test).

tAll non-TNT-exposed.

Table 4 Mutagenic activity in urine for smokers (at least one cigarette within 24 hours of the sampling) and non-smokers with $S$ typhimurium TA 98 with and without metabolic activation $(S-9$ mix $)$

\begin{tabular}{|c|c|c|c|c|c|c|c|}
\hline \multirow[t]{2}{*}{ Test } & \multirow[t]{2}{*}{ Group } & \multicolumn{3}{|c|}{ Smokers } & \multicolumn{3}{|c|}{ Non-smokers } \\
\hline & & No & Unexposed & Exposed & $\mathrm{No}$ & Unexposed & Exposed \\
\hline$+S-9$ & $\begin{array}{l}\text { All } \\
\text { A } \\
\text { B-L }\end{array}$ & $\begin{array}{r}41 \\
7 \\
34\end{array}$ & $\begin{array}{l}522 \pm 525 \\
626 \pm 545 \\
501 \pm 526^{* *}\end{array}$ & $\begin{array}{l}491 \pm 603 \\
750 \pm 438 \\
437 \pm 623\end{array}$ & $\begin{array}{r}32 \\
6 \\
26\end{array}$ & $\begin{array}{l}276 \pm 343 \\
283 \pm 348 \\
274 \pm 349\end{array}$ & $\begin{array}{l}296 \pm 411 \\
711 \pm 655^{*} \\
200 \pm 270\end{array}$ \\
\hline$-S-9$ & $\begin{array}{l}\text { All } \\
\text { A } \\
\text { B-L }\end{array}$ & $\begin{array}{r}40 \\
7 \\
33\end{array}$ & $\begin{array}{l}205 \pm 359 \\
418 \pm 739 \\
159 \pm 206\end{array}$ & $\begin{array}{r}450 \pm 648 \\
1412 \pm 979 \\
246 \pm 293\end{array}$ & $\begin{array}{r}34 \\
7 \\
27\end{array}$ & $\begin{array}{r}116 \pm 252 \\
49 \pm 56 \\
134 \pm 280\end{array}$ & $\begin{array}{r}547 \pm 1069 \\
2156 \pm 1530 \\
130 \pm 181\end{array}$ \\
\hline
\end{tabular}

${ }^{*} \mathrm{p}<0.05$ (difference between non-smokers in group A and B-L; Wilcoxon's rank sum test-p < 0.01 with Student's $t$ test).

${ }^{* *} \mathrm{p}<0.05$ (difference between smokers and non-smokers; Wilcoxon's rank sum test and Student's $t$ test).

\section{Discussion}

An increase in the excretion of genotoxic metabolites (premutagens or mutagens or both) in the urine after occupational exposure was detected only in the subgroups of workers handling TNT. 2,4,6-Trinitrotoluene is produced at the plant and other TNT-isomeres are formed in small amounts as contaminants. 2,4,6-TNT has earlier been shown to be a frame shift mutagen in the Ames assay without metabolic activation ${ }^{25}$ and waste water from TNT producing plants contains several mutagenic com- ponents. ${ }^{2627}$ TNT-metabolites such as 2,6-dinitro4-aminotoluene and 2,4-dinitro-6-aminotoluene have not shown mutagenicity. Transformation of TNT in oxidative systems may occur in addition to metabolism by reduction, although this has not yet been found in man. It is not clear to what extent TNT is excreted unmetabolised in the free or conjugated form through the kidneys. ${ }^{28}$ Nevertheless, in this study we were able with a gas chromatographic technique to detect TNT in the urine of the workers with the highest mutagenic activity.

Falck has estimated the limit value for a 


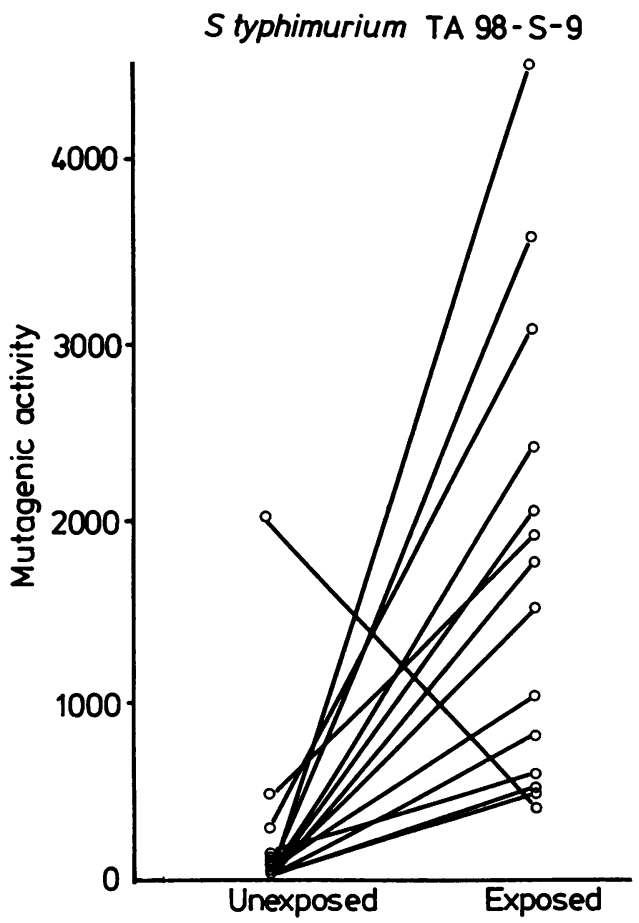

Fig 2 Mutagenic activity (number of revertants/mmol creatinine) in individual unexposed and exposed urine samples from $T N T$-workers $(n=14)$ tested with Salmonella typhimurium TA 98 without metabolic activation.

significantly increased mutagenic activity in the urine from several hundred non-exposed, non-smoking individuals to be about $600 \mathrm{rev} / \mathrm{mmol}$ creat in $S$ typhimurium TA 98 and 300 in $E$ coli WP2 uvrA. ${ }^{21}$ Only the TNT group had a mean value above either of these limits (discounting the effect of smoking detectable with $S$ typhimurium TA 98 using S-9 mix). No sign was found of an increased uptake of base pair substitution mutagens during exposure. The increase in the frame shift mutagen indicating system without metabolic activation was, however, clear in the TNT group. There was also a tendency for increased mutagenic activity when metabolic activation was used, although this was not statistically significant.
Exposure to other mutagenic or premutagenic substances such as dimethylsulphate and acrylonitrile may occur in some of the other production units. Several explanations for the absence of an effect in samples from workers in those units are possible.

(1) No biological uptake due to low exposure.

(2) The exposure is too low for the sensitivity of the assay.

(3) Too few individuals exposed to achieve a significant effect in the group analyses.

(4) The urine metabolites are not mutagenic/ premutagenic or cannot be activated.

(5) The bacterial strains used were not sensitive to the mutagenicity of the chemicals or their metabolites.

Since the handling of such substances is subject to rigorous safety regulations, the first two explanations seem the most plausable. Dinitrotoluenes, which are not produced in the plant but occur in small amounts as contaminants, are less potent mutagens than the trinitrotoluenes. ${ }^{26}$ Mononitrotoluenes which are produced at the plant have little, if any, mutagenic potency and toluene itself is non-mutagenic in bacterial test systems. ${ }^{26}$ No data on the mutagenicity of the urine metabolites of the nitrotoluenes are available.

\section{VALIDITY OF THE RESULTS}

The individual variation in the urinary mutagenio activity has been found to be relatively wide in most studies. ${ }^{29}$ Genetic factors, health and backgroun factors such as diet, medication, smoking, alcohol consumption, and other chemical exposures, may account for this. Smoking, as a source of urinary mutagenicity, has been confirmed by several researchers, ${ }^{29}$ and the effect is usually seen on bacterial strains sensitive to frameshift mutagens. This effect was also seen in the present study. We have not, however, in comparing the questionnaire data on the different exposure subgroups found any other background factors that can explain the main findings in the group analysis. The proportion of smoking individuals is not greater in the TNT group than in the others. The non-smokers in the TNT group showed an increased mutagenic activity in $S$ typhimurium TA 98 with metabolic activation, although the difference between the exposed and unexposed samples did not

Table 5 Thioether concentration ( $\mu \mathrm{mol}$ SH/mmol creatinine) in urine from smokers and non-smokers

\begin{tabular}{|c|c|c|c|c|c|c|}
\hline \multirow[t]{2}{*}{ Group } & \multicolumn{3}{|c|}{ Smokers } & \multicolumn{3}{|c|}{ Non-smokers } \\
\hline & No & Unexposed & Exposed & No & Unexposed & Exposed \\
\hline $\begin{array}{l}\text { All } \\
\text { A } \\
\text { B-L }\end{array}$ & $\begin{array}{r}42 \\
7 \\
35\end{array}$ & $\begin{array}{l}4.2 \pm 1.7 \\
4.4 \pm 1.6 \\
4.1 \pm 1.8\end{array}$ & $\begin{array}{l}4 \cdot 8 \pm 2 \cdot 1 \\
5 \cdot 7 \pm 2 \cdot 4 \\
4 \cdot 7 \pm 2 \cdot 0\end{array}$ & $\begin{array}{r}35 \\
7 \\
28\end{array}$ & $\begin{array}{l}3.6 \pm 2.7 \\
3.8 \pm 2.7 \\
3.6 \pm 2.8\end{array}$ & $\begin{array}{l}3.1 \pm 1.9^{*} \\
2.4 \pm 0.5 \\
3.4 \pm 2.0\end{array}$ \\
\hline
\end{tabular}

${ }^{*} p<0.001$ (difference between smokers and non-smokers; Student's $t$ test). 
reach statistical significance (possibly due to the small number of individuals or variation in the group). Compared with the other non-smokers their exposed values are clearly increased.

As shown above, many of the samples were toxic to the indicator bacteria. This is a general problem with the use of urine for biological testing, and may be due to toxic metabolites at high concentrations or the samples might have been contaminated by toxic substances during preparation. Nevertheless, the numbers of toxic samples are relatively evenly distributed among the exposure subgroups and not associated with any specific exposure. TNT is considered to inhibit the growth of $S$ typhimurium at concentrations above $10 \mu \mathrm{g} / \mathrm{ml}^{25}$ but none of the exposed samples in the TNT group was toxic to the bacteria.

In the prestudy design it was considered important to exclude people with liver disease or disturbed liver function since that may influence their ability to metabolise the genotoxic substances to which they are exposed. TNT is toxic to the liver and such exposure might have caused an increase in the activity of the hepatic enzymes. ${ }^{28}$ Only one individual exposed to TNT was excluded for this reason, however, and no other exposure subgroup was severely reduced.

The sensitivity of the bacterial fluctuation assay when using histidine dependent strains has been discussed as some researchers have found significant amounts of histidine in samples after concentration on XAD-2 resin. ${ }^{30}$ This could cause the growth of non-mutant bacteria leading to a false positive test result. The amount of histidine was checked in the urine concentrates prepared, however, and not found high enough to permit growth of non-revertant bacteria in the assay system used. ${ }^{31}$ Moreover, it is not likely that such an effect would be associated with any specific exposure.

The indicator bacteria $S$ typhimurium TA 98 has some nitroreductase activity. In a recent study by Whong and Edwards TNT and some other nitroaromatic explosives were tested for mutagenicity using a nitroreductase deficient Salmonella strain (TA $100 \mathrm{NRD}){ }^{32}$ In the Ames's plate-incorporation assay TNT showed little, if any, mutagenic effect with this indicator strain. Their conclusion was that "reduced metabolites, possibly hydroxyl amines, are the proximal mutagenic intermediate." It has also been shown that many other nitroarenes depending on nitroreductase activity for mutagenicity are potent animal carcinogens. ${ }^{33} 34$ An explanation for this may be the presence of gastrointestinal nitro reduction in vivo or possibly an alternative metabolisation (ring hydroxylation for example) in mammalian cells. ${ }^{35}$ Consequently, the increase of urine mutagenicity in the TNT workers might not only be a sign of exposure and biological uptake but also an indication of an increased genotoxic risk. At present, however, it is not possible to relate the earlier epidemiological finding of an increased risk of gastric cancer among people who worked at the plant in earlier decades to TNT or any other specific exposures.

\section{THIOETHER ANALYSIS}

Certain foodstuffs - for example, white cabbage and horse radish-give a drastic increase in thioether concentration in the urine after ingestion. ${ }^{36}$ Only a few individuals in this study showed such an increase, and only in the unexposed or preshift samples. No statistically significant differences were noted, neither between the exposed and unexposed samples nor between the exposed and preshift samples for any of the exposure groups. The explanation might be that the method is too insensitive to detect the contribution of thioethers originating from the work environment exposures, even though the method is sensitive enough to detect a constant difference between smokers and non-smokers.

During our later interlaboratory cooperation for modification of the thioether method some critical steps in the analysis have been identified. Thawing and mixing of the sample must be done in a careful and standardised way. The number of extractions could be increased for maximal yield and the time between neutralisation and colour reaction must be short to eliminate the risk of oxidation. Possibly, deficiencies in our earlier analysis techniques have left existing differences in thioether concentrations unrevealed.

\section{EXPOSURE}

Each exposure group consisted of workers producing or handling, or both, the same main substances. In most cases the groups worked in separate buildings. Dust exposure occurred mainly when raw materials were filled or when the dried product was packed. TNT is mainly absorbed through the skin and usually to a lesser extent through the lungs or the gastrointestinal tract. ${ }^{37}$ The measured air concentrations in the production units are therefore not necessarily representative of the biologically relevant exposure. Skin contamination, however, is most likely to occur where the dust concentration is high. Therefore the exposure related increase in the mutagenic activity of the workers in those departments supports a causal relation between exposure to TNT and the increased urinary mutagenic activity. The average TNT concentration in the air has been well below the recommended ACGIH value of $0.5 \mathrm{mg} / \mathrm{m}^{3}$. In Finland the TLV is $1.5 \mathrm{mg} / \mathrm{m}^{3}$; there is no Swedish standard.

There were no indications that any of the other chemicals had made a significant contribution to the mutagenicity in the samples exposed to TNT. Work- 
ers on the same shift and area have somewhat specialised duties that may result in considerable differences in exposure. Occasional high exposures may take place when production is interrupted accidentally and when repair or cleaning work is performed. The industrial hygienists, the production leaders, and the workers agreed, however, that exposures during the shifts under study were normal.

This study was made possible by the wholehearted cooperation of the safety committee and the health personnel at Bofors Nobel Kemi. We thank Ms Rosmarie Wigren for performing the thioether analyses and Dr Kai Falck and Professor Harri Vainio for good advice in the design of the study. Associate Professor Lennart Bodin has guided the statistical analyses.

The study was supported by a grant from the Swedish Work Environment Fund (n:o 81-0196).

\section{Requests for reprints to: Dr G Ahlborg jr.}

\section{References}

${ }^{1}$ Hemminki K, Sorsa M, Vainio $H$. Genetic risks caused by occupational chemicals: use of experimental methods and occupational risk group monitoring in the detection of environmental chemicals causing mutations, cancer and malformations. Scand J Work Environ Health 1979;5:307-27.

${ }^{2}$ Baden JM, Kelley M, Cheung A, Mortelmans K. Lack of mutagens in urines of operating room personnel. Anesthesiology 1980;53:195-8.

${ }^{3}$ McCoy EC, Hankel R, Robbins K, Rosenkranz HS, Giuffrida JG, Bizzari DU. Presence of mutagenic substances in the urine of anesthesiologists. Mutat Res 1978;53:71.

${ }^{4}$ Gibson JF, Gompertz D. Mutagenicity of urine from nurses handling cytotoxic drugs. Lancet 1984; 1 :100-1.

${ }^{5}$ Kilian DJ, Pullin TG, Conner TH, Legator MS, Edwards HN. Mutagenicity of epichlorhydrin in the bacterial assay system: evaluation by direct in vitro activity of urine from exposed humans and mice. Mutat Res 1978;53:72.

${ }^{6}$ Schimberg R, Skyttä E, Falck K. Belastung von Eisengiessereiarbeitern durch mutagene polycyclische aromatische Kohlenwasserstoffe. Staub-Reinhalting der Luft 1981;41: 421-4.

${ }^{7}$ Møller M, Dybing E. Mutagenicity studies with urine concentrates from coke plant workers. Scand J Work Environ Health 1980;6:216-20.

${ }^{8}$ Pasquini R, Monarca S, Sforzolini GS, Conti R, Fagioli F. Mutagens in urine of carbon electrode workers. Int Arch Occup Environ Health 1982;50:387-95.

${ }^{9}$ Green MHL, Muriel WJ, Bridges BA. Use of a simplified fluctuation test to detect low levels of mutagens. Mutat Res 1976;38:33-42.

${ }^{10}$ Falck K, Sorsa M, Vainio H. Mutagenicity in urine of workers in rubber industry. Mutat Res 1980;79:45-52.

${ }^{11}$ Falck K, Gröhn P, Sorsa M, et al. Mutagenicity in urine of nurses handling cytostatic drugs. Lancet 1979;i:1250-1.

${ }^{12}$ Sorsa M, Falck K, Norppa H, Vainio H. Monitoring genotoxicity in the occupational environment. Scand J Work Environ Health 1981;7:61-5.
${ }^{13}$ van Doorn R, Bos RP, Leijdeckers CM, et al. Thioether concentration and mutagenicity of urine from cigarette smokers. Int Arch Occup Environ Health 1979;43:159-66.

${ }^{14}$ Heinonen T, Kytoniemi V, Sorsa M, Vainio H. Urinary excretion of thioethers among low-tar and medium-tar cigarette smokers. Int Arch Occup Environ Health 1983;52:11-6.

${ }^{15}$ Vainio H, Savolainen H, Kilpikari I. Urinary thioether of employees of a chemical plant. Br J Ind Med 1978;35:232-4.

${ }^{16}$ van Doorn R, Leijdekkers CM, Bos RP, Brouns RME, Henderson PT. Detection of human exposure to electrophilic compounds by assay of thioether detoxication products in urine. Ann Occup Hyg 1981;24:77-92.

${ }^{17}$ van Doorn R, Leijdekkers CM, Bos RP, Brouns RME, Henderson PT. Enhanced excretion of thioethers in urine of operators of chemical waste incinerators. Br J Ind Med 1981;38:187-90.

${ }^{18} \mathrm{Jagun} O$, Ryan M, Waldron HA. Urinary thioether excretion in nurses handling cytotoxic drugs. Lancet 1982;ii:443-4.

${ }^{19}$ Sorsa M, Falck K, Mäki-Paakanen J, Vainio H. Genotoxic hazards in the rubber industry. Scand $J$ Work Environ Health 1983;9:103-7.

${ }^{20}$ Yamasaki E, Ames BN. The concentration of mutagens from urine by XAD-2 adsorption: cigarette smokers have mutagenic urine. Proc Natl Acad Sci USA 1977;74:3555-9.

${ }^{21}$ Falck K. Application of the bacterial urinary mutagenicity assay in detection of exposure to genotoxic chemicals. Helsinki: Institute of Occupational Health, 1982. (Academic dissertation.)

${ }^{22}$ Clark LC, Thompson HL. Determination of creatinine and creatinine in urine. Anal Chem 1949;21:1218-21.

${ }^{23}$ Gelbart SM, Sontag SJ. Mutagenic urine in cirrhosis. Lancet 1980;i:894-6.

${ }^{24}$ Colton T. Statistics in medicine. Boston: Little, Brown and Company, 1974.

${ }^{25}$ Won WD, DiSalvo LH, Ng J. Toxicity and mutagenicity of 2,4,6,-trinitrotoluene and its microbial metabolites. Appl Environ Microbiol 1976;31:576-80.

${ }^{26}$ Spangford RJ, Mortelmans KE, Griffin AF, Simmon VP Mutagenicity in Salmonella typhimurium and structure-activit relationships of wastewater components emanating from the manufacture of trinitrotoluene. Environ Mutagen 1982;4:163-79.

${ }^{27}$ Sundvall A, Marklund H, Rannug U. The mutagenicity on Salmonella typhimurium of nitrobenzoic acids and other wastewater components generated in the production of nitrobenzoic acids and nitrotoluenes. Mutat Res 1984;137:71-8.

${ }^{28}$ Zakhair S, Villaume JE. Occupational health and safety aspects of 2,4,6-trinitrotoluene (TNT). A literature review-problem definition studies on selected toxic chemicals. Vol 3. Philadelphia: Science Information Services Organization, Franklin Institute Research Laboratories 1978:43-52.

${ }^{29}$ Vainio H, Sorsa M, Falck K. Bacterial urinary assay in monitoring exposure to mutagens and carcinogens. In: Berlin A, Draper M, Hemminki K, Vainio H, eds. Monitoring of human exposure to carcinogenic and mutagenic agents. Lyon: International Agency for Research on Cancer (in press).

${ }^{30}$ Gibson JF, Baxter PJ, Hedmore-Whitty RB, Gompertz D. Urinary mutagenicity assay: a problem arising from the presence of histidine associated growth factors in XAD-2 prepared urine concentrates with particular relevance to assays carried out using the bacterial fluctuation test. Carcinogenesis 1983; 4:1471-6.

${ }^{31}$ Einistö P, Sorsa M. Mutagenic activity in urine of active and passive smokers. Mutat Res (in press).

32 Whong W-Z, Edwards GS. Genotoxic activity of nitroaromatic explosives and related compounds in Salmonella typhimurium. Mutat Res 1984;136:209-15.

${ }^{33}$ Blumer JL, Frieman A, Meyer LW, Fairchild E, Webster LT, Spec WT. Relative importance of bacterial and mammalian nitro- 0 reductases for niridazole mutagenesis. Cancer Res 1980;40:4595-605.

${ }^{34}$ Rosenkranz HS, Memelstein R. Mutagenicity and genotoxicity of 
nitroarenes. All nitro-containing chemicals were not created equal. Mutat Res 1983;114:217-67.

${ }^{35}$ Rosenkranz EJ, McCoy EC, Mermelstein R, Rosenkranz HS. Evidence for the existence of distinct nitroreductases in Salmonella typhimurium-roles in mutagenesis. Carcinogen 1982;5:121-3.

${ }^{36}$ Aringer L, Hogstedt C, Lidums V, Svensson E, Wrange R. Utsöndring av tioetrar $\mathrm{i}$ urinen som biologiskt mått på toxisk exponering. Undersǒkning av ett referensmaterial. (Excretion of thioethers in urine as a biological measurement of toxic exposure. A reference material. Abstract in Swedish.) Hygiea 1982;91:129.

${ }^{37}$ Hathaway JA. Trinitrotoluene: a review of reported dose-related effects providing documentation for a workplace standard. J Occup Med 1977;19:341-5.

\section{The September 1985 issue}

\section{THE SEPTEMBER 1985 ISSUE CONTAINS THE FOLLOWING PAPERS}

\section{Editorial}

Does acute toxicity testing tell us anything useful? Methyl isocyanate as a test case A G SALMON

Behavioural evaluation of workers exposed to mixtures of organic solvents N A MAIZLISH, G D LANGOLF, L W WHITEHEAD, L J FINE, J W ALBERS, J GOLDBERG, AND P SMITH

Influence of organic solvent mixtures on biological membranes CHRISTINA GUSTAFSON AND C TAGESSON

Normal serum activities of liver enzymes in Swedish paint industry workers with heavy exposure to organic solvents I LUNDBERG AND MARIANNE HÅKANSSON

Lung function measurements over 21 days shiftwork in steelworkers from a strandcasting department B NEMERY, R VAN LEEMPUTTEN, E GOEMAERE, C VERITER, AND L BRASSEUR

Ventilatory decrements in former asbestos cement workers: a four year follow up C-G OHLSON, L BODIN, T RYDMAN, C HOGSTEDT
Protective effect of selenium on lung cancer in smelter workers L GERHARDSSON, D BRUNE, I G F NORDBERG, AND P O WESTER

Gastric cancer in coal miners: a case-control study in a coal mining area G M H SWAEN, C W H M AERDTS, F STURMANS, J J M SLANGEN, AND P KNIPSCHILD

Changes in permeability of the alveolar-capillary barrier in firefighters BARBARA D MINTY, D ROYSTON, J G JONES, D J SMITH, CAROLINE S M SEARING, AND M BEELEY

Quantitative mineralogical analysis of small samples of china clay using $x$ ray diffractometry $P$ D SALT

Dissolution of metals by human and rabbit alveolar macrophages MARGOT LUNDBORG, A EKLUND, B LIND, AND P CAMNER

Correspondence

Book review

Notice

Copies are still available and may be obtained from the PUBLISHING MANAGER, BRITISH MEDICAL ASSOCIATION, TAVISTOCK SQUARE, LONDON WCIH 9JR. 